\title{
Fenton and solar photo-Fenton processes for the removal of chlorpyrifos insecticide in wastewater
}

\author{
Youssef Samet*, Emna Hmani and Ridha Abdelhédi \\ UR Electrochimie et Environnement, Department of Materials Engineering, National Engineering School of Sfax, \\ BPW 3038 Sfax, University of Sfax, Tunisia
}

\begin{abstract}
The degradation of chlorpyrifos in water by Fenton $\left(\mathrm{H}_{2} \mathrm{O}_{2} / \mathrm{Fe}^{2+}\right)$ and solar photo-Fenton $\left(\mathrm{H}_{2} \mathrm{O}_{2} / \mathrm{Fe}^{2+} /\right.$ solar light) processes was investigated. A laboratory-scale reactor was designed to evaluate and select the optimal oxidation condition. The degradation rate is strongly dependent on $\mathrm{pH}$, temperature, $\mathrm{H}_{2} \mathrm{O}_{2}$ dosing rate, and initial concentrations of the insecticide and $\mathrm{Fe}^{2+}$. The kinetics of organic matter decay was evaluated by means of chemical oxygen demand (COD) measurement. Overall kinetics can be described by a pseudo-second-order rate equation with respect to COD. The optimum conditions were obtained at $\mathrm{pH} 3, \mathrm{H}_{2} \mathrm{O}_{2}$ dosing rate $120 \mathrm{mg} \cdot \mathrm{min}^{-1},\left[\mathrm{Fe}^{2+}\right]_{0} 5.0 \mathrm{mM}$, initial COD $1330 \mathrm{mg} \cdot \ell^{-1}$ and $35^{\circ} \mathrm{C}$ for the Fenton process. However, in the solar photo-Fenton process, the degradation rate increased significantly. To achieve $90 \%$ of COD removal, the solar photo-Fenton process needs 50\% less time than that used in the Fenton process which translates to a $50 \%$ gain of $\mathrm{H}_{2} \mathrm{O}_{2}$.
\end{abstract}

Keywords: chlorpyrifos; degradation kinetic; Fenton; solar photo-Fenton; COD removal

\section{Introduction}

The use of insecticides, herbicides, fungicides, etc., grouped under the name of pesticides, has led to improved yields and diversity of crops to meet the nutritional demand related to the increase in world population. However, this use has also had indirect and harmful effects on the environment. Studies have shown the presence of pesticide residues in food (Cunnif, 1995), groundwater and surface water (Di Corcia and Marchetti, 1992). Various technologies have been proposed for the removal of pesticides from water. Conventional techniques, such as physical methods of mass transfer (flocculation, filtration, precipitation, adsorption onto active charcoal, etc.), incineration, or the biological pathway, are either ineffective in the face of the extent of this pollution, or result in crippling costs, or are a source of secondary pollution (sludge formation); hence there is a need to seek better alternatives.

In this context, advanced oxidation processes (AOPs) have considerable potential for becoming feasible alternatives for the remediation of contaminated wastewater. AOPs are based on the generation and subsequent reactions of hydroxyl radicals $\left(\mathrm{OH}^{*}\right)$. These are short-lived, powerful oxidising agents, which react by second-order kinetics with the majority of organic substances with low selectivity (Esplugas et al., 2002). $\mathrm{OH}^{*}$ are produced in situ by chemical, electrochemical and/or photochemical reactions in AOP systems.

Among many AOPs, Fenton $\left(\mathrm{H}_{2} \mathrm{O}_{2} / \mathrm{Fe}(\mathrm{II})\right)$ and solar photoFenton treatment processes (combination of $\mathrm{H}_{2} \mathrm{O}_{2}, \mathrm{Fe}(\mathrm{II})$ and solar irradiation) have been proven to be effective in degradation and mineralisation of single organic toxicants and the mixtures of various organic wastes (Xu et al., 2007).

The photo-Fenton process can be divided into the following stages (Pignatello, 1992; Bossmann et al., 1998): the first

\footnotetext{
* To whom all correspondence should be addressed.

If (00216) 9866 0766; fax: (00216) 7427 4437;

e-mail: youssef.samet@fss.rnu.tn

Received 10 October 2011; accepted in revised form 25 June 2012.
}

step is the so-called Fenton reaction, in which ferrous ions are oxidised to ferric ions in acidic aqueous solution, as shown in Eq. (1), giving rise to hydroxyl radicals:

$$
\mathrm{Fe}^{2+}+\mathrm{H}_{2} \mathrm{O}_{2} \rightarrow \mathrm{Fe}^{3+}+\mathrm{OH}^{-}+\mathrm{OH}^{\cdot}
$$

The ferric ions, represented by the complex $\mathrm{Fe}(\mathrm{OH})^{2+}$, is reduced back to $\mathrm{Fe}^{2+}$ by $\mathrm{UV}$-visible irradiation according to Eq. (2):

$$
\mathrm{Fe}(\mathrm{OH})^{2+}+h v \rightarrow \mathrm{Fe}^{2+}+\mathrm{OH}^{\cdot}(\lambda<450 \mathrm{~nm})
$$

The ferric species can also form complexes with the initial organic compounds and/or degradation products, leading to photo-reduction back to $\mathrm{Fe}^{2+}$, according to Eq. (3):

$$
\mathrm{Fe}\left(\mathrm{RCO}_{2}\right)^{2+}+h v \rightarrow \mathrm{Fe}^{2+}+\mathrm{R}^{\cdot}+\mathrm{CO}_{2}(\lambda<500 \mathrm{~nm})
$$

The $\mathrm{OH}^{\bullet}$ species formed will then attack the organic substrates present in the wastewater. Nevertheless, numerous competitive reactions can also occur, namely, the following, which negatively affect the oxidation process (Harber and Weiss, 1934; Walling, 1975; Kang and Hwang, 2000):

$$
\begin{aligned}
& \mathrm{Fe}^{2+}+\mathrm{OH}^{\cdot} \rightarrow \mathrm{Fe}^{3+}+\mathrm{OH}^{-} \\
& \mathrm{H}_{2} \mathrm{O}_{2}+\mathrm{OH}^{\cdot} \rightarrow \mathrm{HO}_{2}^{\cdot}+\mathrm{H}_{2} \mathrm{O}
\end{aligned}
$$

This network of consecutive and parallel reactions results in complex reaction kinetics. To overcome these difficulties, most of the kinetic studies focused on single component degradation or, in the case of complex effluents, the overall kinetics was analysed instead.

The use of Fenton and photo-Fenton processes in the treatment of pesticide-containing wastewater is a recent application. The degradation of triazine herbicides (Burrows et al., 2002), methylparathion (Chiron et al., 1999), fenuron (Acero et al., 2002) and diuron (Burrows et al., 2002) are known examples.

In this work, the efficiency of AOPs in the remediation of wastewater contaminated with the insecticide chlorpyrifos 
<smiles>CCOP(=S)(OCC)Oc1nc(Cl)c(Cl)cc1Cl</smiles>

Figure 1

Chemical structure of chlorpyrifos

(Fig. 1), employed extensively in agriculture in Tunisia, was investigated in a laboratory-scale reactor. The effects of $\mathrm{Fe}^{2+}$ and chlorpyrifos concentrations, $\mathrm{H}_{2} \mathrm{O}_{2}$ dosing rate, $\mathrm{pH}$ and temperature were investigated in the case of the Fenton process and the optimum conditions were applied in the case of the solar photo-Fenton system.

It should be noted that the chlorpyrifos oxidation pathway using different AOPs, such as photo-Fenton (Murillo et al., 2010), ozonation (Meng et al., 2010), and electrochemical (Samet et al., 2010) AOPs, has been investigated. The main identified by-product is chlorpyrifos-oxon.

\section{Experimental}

A schematic view of the experimental device used in this work is shown in Fig. 2. All experiments were carried out with the same equipment. The equipment consisted of an aluminium frame ( $0.5 \mathrm{~m}$ length; $0.5 \mathrm{~m}$ width and $0.6 \mathrm{~m}$ height), which supports: (i) A platform of aluminium placed $34^{\circ}$ to the horizontal and on which was fixed a solar reactor consisting of a borosilicate glass tube (4.5 m length, an inner diameter of 6 $\mathrm{mm}$ and outer diameter of $8 \mathrm{~mm}$; and snake-shaped); and (ii) an Erlenmeyer flask (Pyrex $1 \ell$ ) in which the chlorpyrifos solution was prepared with bi-distilled water. This Erlenmeyer flask was immersed in a water bath in order to control the working temperature using a thermostat (Julabo Labortechnik GMBH, Sellback, Germany). The treated volume was $1 \ell$, and the solution was circulated through the reactor using a peristaltic pump (Cole-Parmer Instrument, Chicago, Illinois 60648 USA) with a flow rate of $140 \mathrm{~m} \ell \cdot \mathrm{min}^{-1}$. This pump was simultaneously used to generate the flow of the $\mathrm{H}_{2} \mathrm{O}_{2}$ solution from the Erlenmeyer flask with a constant rate of $0.7 \mathrm{~m} \ell \cdot \mathrm{min}^{-1}$. The ferrous sulphate was introduced into the solution at start-up. The solutions were continuously stirred using a magnetic stirrer (Tacussel, France).

The solar photo-Fenton experiments were performed at the Electrochemical and Environmental Laboratory, National Engineering School of Sfax (approximately $3 \mathrm{~m}$ amsl, latitude: $34^{\circ} 44^{\prime} \mathrm{N}$, longitude: $10^{\circ} 45^{\prime} \mathrm{E}$ ), Tunisia. All tests were conducted between 11:00 and 15:00 on sunny days from April to June 2010 . The global solar radiation intensity was approximately $850 \mathrm{~W} \cdot \mathrm{m}^{-2}$.

For tests using only the Fenton reagent, the experimental device was kept away from solar radiation by covering it with a black plastic film and aluminium foil.

Samples $(0.5 \mathrm{~m} \ell)$ were withdrawn from the reactor at selected intervals for COD analysis. COD was measured using a spectrophotometer (Shimadzu UV-Mini 1240 UV/Vis Spectrophotometer) using a dichromate solution as the oxidant in strong acid media (Kolthof et al., 1969).

Since the residual $\mathrm{H}_{2} \mathrm{O}_{2}$ interferes with the measurement of COD (Kang et al., 2002), the residual amount of $\mathrm{H}_{2} \mathrm{O}_{2}$ was also measured, using the permanganate titration. This method is suitable for measuring solutions of hydrogen peroxide in the

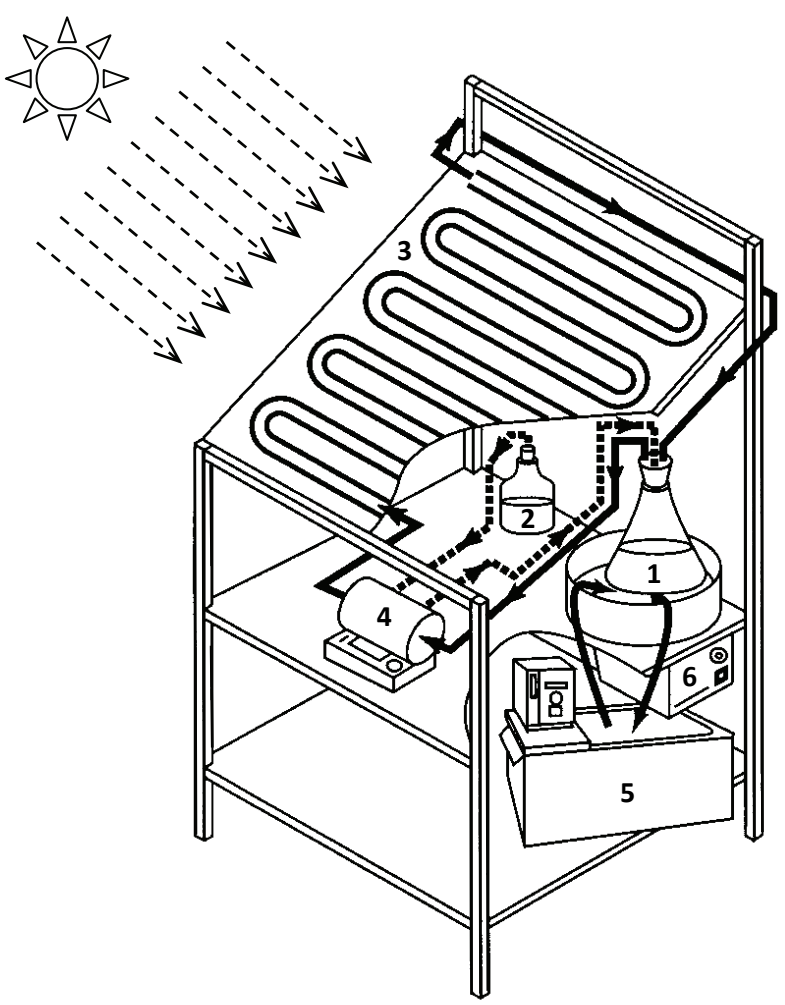

Figure 2

Scheme of the experimental installation. (1) Erlenmeyer flask (chlorpyrifos solution); (2) $\mathrm{H}_{2} \mathrm{O}_{2}$ solution; (3) solar reactor;

(4) peristaltic pump; (5) thermostatic bath; (6) magnetic stirrer.

range 0.25 to $70 \% \mathrm{wt}$ (Lin and Lo, 1997). Correction of hydrogen peroxide interference was performed to COD analysis.

In this work, all solutions were prepared in the laboratory. These solutions contained quantities of chlorpyrifos taken from an emulsifiable concentrate (DURSBAN* 4, from Dow Agrosciences) containing $480 \mathrm{~g} \cdot \ell^{-1}(44.6 \% \mathrm{~W} / \mathrm{W})$ chlorpyrifos. All of the solutions were freshly prepared with double-distilled water. Sulphuric acid of analytical grade was employed for $\mathrm{pH}$ adjustment. Ferrous sulphate heptahydrate $\left(\mathrm{FeSO}_{4} 7 \mathrm{H}_{2} \mathrm{O}\right)$ was obtained from Riedel-de Haën (Seelze-Hannover, Germany) and used as the Fe(II) catalyst. Hydrogen peroxide (35\% v/v) and sulphuric acid were provided by Merck (Darmstadt, Germany).

All samples were tested in duplicate, and the test was reproduced 3 times for each sample, so that the relative errors could be minimised. All of the figures show the average values.

Initial conditions $\left(\mathrm{COD}_{0}=465 \mathrm{mg} \cdot \ell^{-1}>200 \mathrm{mg} \cdot \ell^{-1},\left[\mathrm{Fe}^{2+}\right]_{0}=\right.$ $0.5 \mathrm{mM}$ and $\mathrm{H}_{2} \mathrm{O}_{2}$ dosing rate $=30 \mathrm{mg} \cdot \mathrm{min}^{-1}$ ) were chosen after preliminary tests which lead to quantitative decrease in organic matter. A pHof 3 was chosen because Fenton or photo-Fenton processes require $\mathrm{Fe}^{2+}$ and $\mathrm{Fe}^{3+}$ ions. These species are more stable at this value of $\mathrm{pH}$, as indicated by the Pourbaix diagram. At $\mathrm{pH}>3 \mathrm{Fe}^{3+}$ will be precipitated to $\mathrm{Fe}(\mathrm{OH})_{3}$. The ambient temperature, $T$, was $25^{\circ} \mathrm{C}$.

\section{Results and discussion}

\section{Oxidation of chlorpyrifos by the Fenton process}

\section{Effect of the dosing rate of hydrogen peroxide}

The dosing rate of $\mathrm{H}_{2} \mathrm{O}_{2}$ is considered to be one of the most important factors which should be considered in the Fenton 


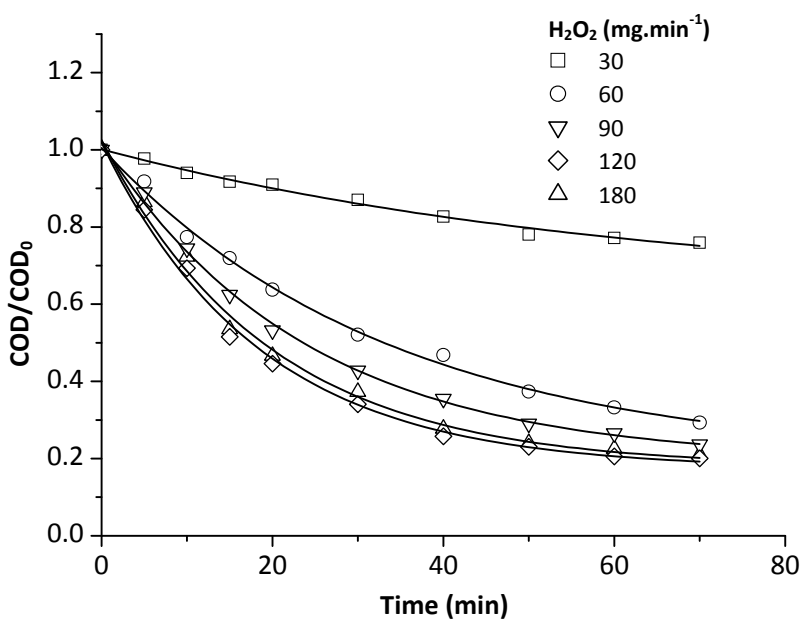

Figure 3

Effect of hydrogen peroxide dosing rate on the trend of $C O D / C O D$ ratio during the oxidation of chlorpyrifos solution by Fenton process. $\left[\mathrm{Fe}^{2+}\right]_{0}=2.0 \mathrm{mM} ; \mathrm{COD}_{0}=1330 \mathrm{mg} \cdot \ell^{-1}$, $\mathrm{pH}=3$ and $T=25^{\circ} \mathrm{C}$

\begin{tabular}{|l|c|c|c|c|c|}
\hline \multicolumn{7}{|c|}{ Table 1 } \\
Kinetic degradation by Fenton process \\
\hline $\mathrm{H}_{2} \mathrm{O}_{2}\left(\mathrm{mg} \cdot \mathrm{min}^{-1}\right)$ & 30 & 60 & 90 & 120 \\
\hline Pseudo-first-order & $R^{2}$ & 0.9683 & 0.9514 & 0.9342 & 0.8942 \\
\hline Pseudo-second-order & $R^{2}$ & 0.9914 & 0.9927 & 0.9891 & 0.9818 \\
\hline$k_{\text {app }} \times 10^{2}\left(\ell \cdot \mathrm{g}^{-1} \cdot \mathrm{min}^{-1}\right)$ & 0.37 & 2.46 & 3.46 & 4.34 \\
\hline
\end{tabular}

process. The effect of the dosing rate of hydrogen peroxide on the efficiency of the oxidation process was investigated under the operating conditions $\left(\mathrm{COD}_{0}=1330 \mathrm{mg} \cdot \ell^{-1},\left[\mathrm{Fe}^{2+}\right]_{0}=\right.$ $2 \mathrm{mM}, \mathrm{pH}=3$ and $T=25^{\circ} \mathrm{C}$ ) (Fig. 3). It was found that COD removal efficiency increases with increasing the dosing rate of hydrogen peroxide from $30 \mathrm{mg} \cdot \mathrm{min}^{-1}$ to $180 \mathrm{mg} \cdot \mathrm{min}^{-1}$. The highest per cent removal of COD was attained at 70 min when using a $\mathrm{H}_{2} \mathrm{O}_{2}$ dosing rate of $120 \mathrm{mg} \cdot \mathrm{min}^{-1}$, so further addition of $\mathrm{H}_{2} \mathrm{O}_{2}$ is not necessary. Excessive $\mathrm{H}_{2} \mathrm{O}_{2}$ reacts with $\mathrm{OH}^{\cdot}$ (Eq. (5)) competing with organic pollutants and consequently reducing treatment efficiency.

In all tests, the drop in COD was more significant during the first few minutes of the reaction, when the concentration of organic matter is high. This was clearly observed in the case of the $120 \mathrm{mg} \cdot \mathrm{min}^{-1} \mathrm{H}_{2} \mathrm{O}_{2}$ dosing rate. The data presented in Fig. 3 clearly indicate that the pseudo-second-order model gives better prediction than the pseudo-first-order model for COD removal, as indicated by the higher regression coefficients $\left(R^{2}\right)$ (Table 1).

It is worth noting that several authors have reported that the decaying profile of COD obtained by Fenton oxidation of organic molecules can follow pseudo-second-order kinetics (Guedes et al., 2003; Ratanatamskul and Auesuntrachun, 2009; Argun and Karatas, 2011; Derco et al., 2010).

If we suppose that the hydroxyl radical concentration is constant during treatment, the COD removal rate $r$ can be given by the following equation:

$$
r=-\frac{\mathrm{dCOD}}{\mathrm{d} t}=k\left[\mathrm{OH}^{*}\right]^{\alpha} \mathrm{COD}^{2}=k_{\mathrm{app}} \mathrm{COD}^{2}
$$

where:

$\alpha$ is the reaction order related to the hydroxyl radicals $k$ is the real rate constant

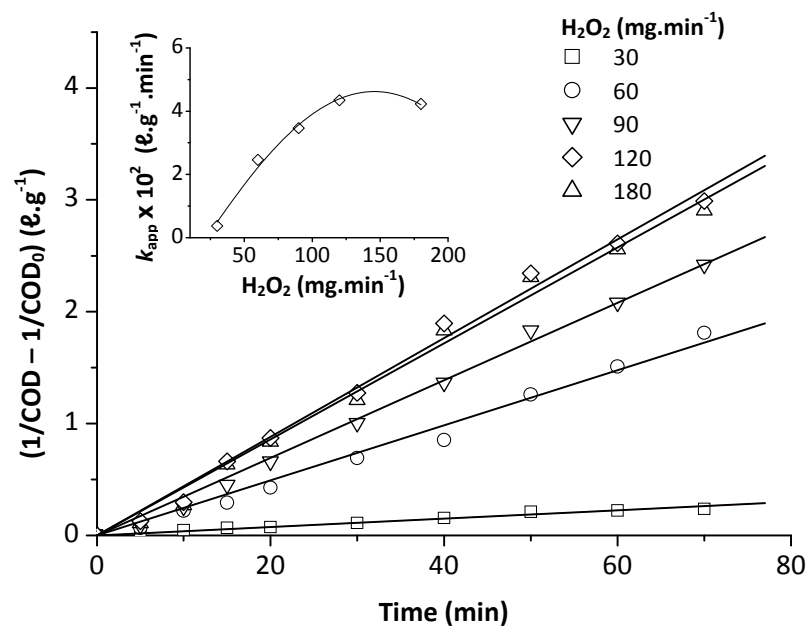

Figure 4

Plot of (1/COD $\left.-1 / C O D_{0}\right)$ versus time at different dosing rate of hydrogen peroxide. The inset panel shows $k_{\text {app }}$ evolution at different dosing rate of $\mathrm{H}_{2} \mathrm{O}_{2}$. COD $=1330 \mathrm{mg} \cdot \ell^{-1} ;\left[\mathrm{Fe}^{2+}\right]_{0}$ $=2.0 \mathrm{mM} ; \mathrm{pH}=3$ and $\mathrm{T}=25^{\circ} \mathrm{C}$.

$k_{\text {app }}$ is the global apparent rate constant for COD removal.

Integration of this equation subject to the initial condition COD $=\mathrm{COD}_{0}$ at $t=0$ leads to the following equation:

$$
\frac{1}{\mathrm{COD}}-\frac{1}{\mathrm{COD}_{0}}=k_{\text {app }} t
$$

In this case, a plot of $1 / \mathrm{COD}-1 / \mathrm{COD}_{0}$ versus time in every experiment must lead to a straight line, with a slope $=k_{\text {app }}$. For example, Fig. 4 shows this plot related to Fig. 3.

The inset of Fig. 4 shows the variation of the apparent rate constant values, at different $\mathrm{H}_{2} \mathrm{O}_{2}$ dosing rates, calculated from the straight lines obtained when considering a pseudo-secondorder reaction. $k_{\text {app }}$ increased significantly when the dosing rate of $\mathrm{H}_{2} \mathrm{O}_{2}$ increased, due to the effect of the additional produced $\mathrm{OH}^{\cdot}$ radicals, but above $120 \mathrm{mg} \cdot \mathrm{min}^{-1} \mathrm{H}_{2} \mathrm{O}_{2}$ dosing rate, the improvement was not obvious. Hence, $120 \mathrm{mg} \cdot \mathrm{min}^{-1} \mathrm{H}_{2} \mathrm{O}_{2}$ appears to be an optimal dosing rate.

\section{Effect of the initial chlorpyrifos concentration}

The effect of chlorpyrifos concentration on the degradation efficiency was investigated at different initial concentrations $\left(\mathrm{COD}_{0}: 465,825\right.$ and $\left.1330 \mathrm{mg} \cdot \ell^{-1}\right)$, as presented in Fig. 5. It can be observed that the COD removal decreased with the increase of the initial concentration of the pollutant. Almost $90 \%$ of COD removal was achieved after about 40 and 60 min reaction time for $\mathrm{COD}_{0} 465$ and $825 \mathrm{mg} \cdot \ell^{-1}$, respectively. Longer reaction time did not improve the COD per cent removal. However, at high chlorpyrifos concentrations the removal of COD requires more time and thus greater quantities of $\mathrm{H}_{2} \mathrm{O}_{2}$ (e.g. the per cent removal of COD is about $77 \%$ after 70 min when using $\left.\mathrm{COD}_{0}=1330 \mathrm{mg} \cdot \ell^{-1}\right)$. The reason for this is that when the concentration of chlorpyrifos increases, the quantity of hydroxyl radicals produced continuously with time does not increase accordingly; hence the removal rate decreases. Also, from the inset of Fig. 5 it can be seen that $k_{\text {app }}$ decreased with COD $_{0}$. This behaviour was similar to that reported for other studies (e.g. Tamimi et al., 2008; Lucas and Peres, 2006; Modirshahla et al., 2007). 


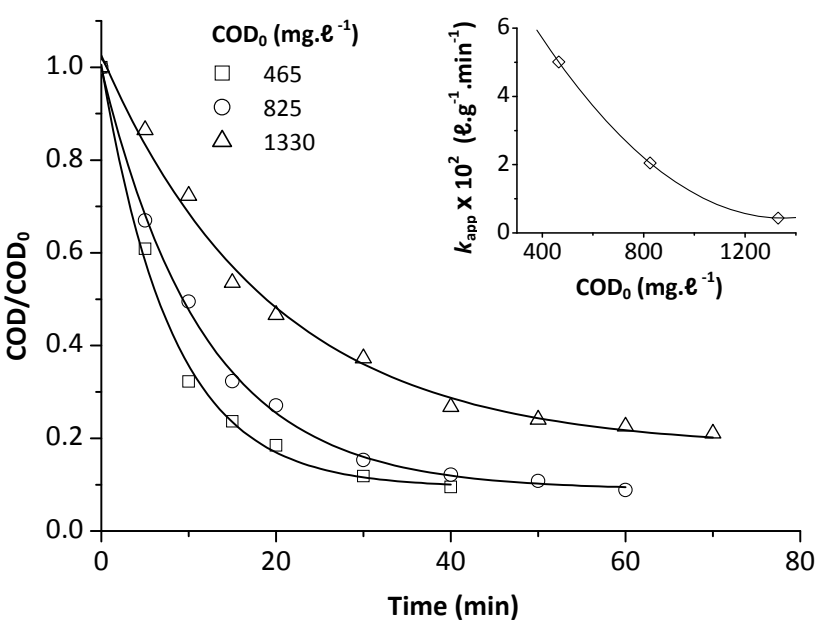

Figure 5

Effect of the initial concentration of chlorpyrifos on the COD removal by the Fenton process. The inset panel shows $k$ evolution at different initial COD. Dosing rate of $\mathrm{H}_{2} \mathrm{O}_{2} 12 \mathrm{O}$ $\mathrm{mg} \cdot \mathrm{min}^{-1} ;\left[\mathrm{Fe}^{2+}\right]_{0}=2.0 \mathrm{mM} ; \mathrm{pH}=3$ and $\mathrm{T}=25^{\circ} \mathrm{C}$.

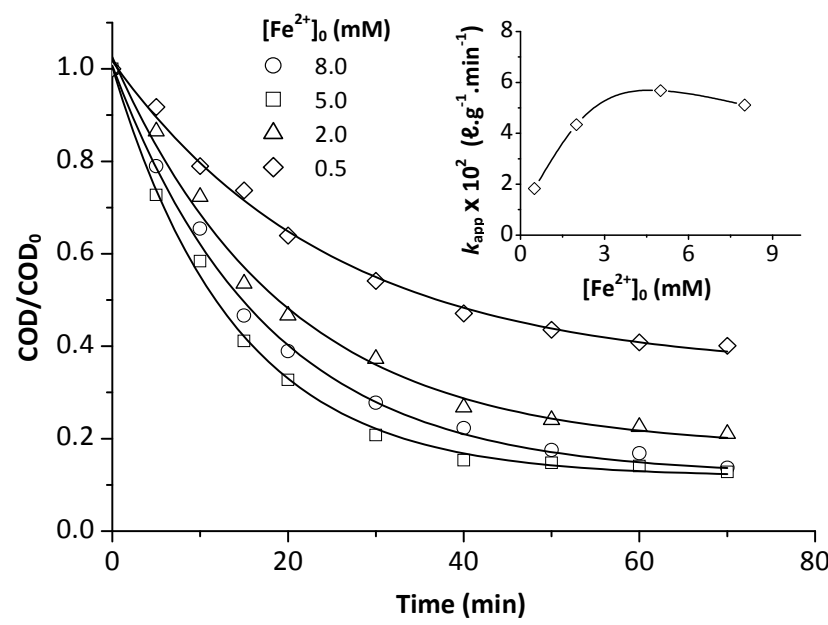

Figure 6

Effect of the initial concentration of $\mathrm{Fe}^{2+}$ on the COD removal by Fenton process. The inset panel shows $k_{\text {app }}$ evolution at different $\mathrm{Fe}^{2+}$ concentrations. $\mathrm{COD}=1330 \mathrm{mg} \cdot \ell^{-1}$; Dosing rate of $\mathrm{H}_{2} \mathrm{O}_{2}$ $120 \mathrm{mg} \cdot \mathrm{min}^{-1} ; \mathrm{pH}=3$ and $\mathrm{T}=25^{\circ} \mathrm{C}$.

\section{Effect of the initial concentration of ferrous iron}

The amount of ferrous ion is one of the main parameters which influences the Fenton and photo-Fenton processes. In this study, to obtain the optimal initial $\mathrm{Fe}^{2+}$ concentration, the investigation was carried out in the range of $0.5-8.0 \mathrm{mM}$ $\mathrm{Fe}^{2+}$, at $\mathrm{pH} 3$ and $\mathrm{H}_{2} \mathrm{O}_{2}$ dosing rate $120 \mathrm{mg} \cdot \mathrm{min}^{-1}$. The results are shown in Fig. 6.

It can be seen that the removal rate of COD clearly increased with the increasing amount of $\mathrm{Fe}^{2+}$, in the range of $0.5-5.0 \mathrm{mM} ; k_{\text {app }}$ increased from 0.018 to $0.056 \ell \cdot \mathrm{g}^{-1} \mathrm{~min}^{-1}$. It was known that $\mathrm{Fe}^{2+}$ had a catalytic decomposition effect on $\mathrm{H}_{2} \mathrm{O}_{2}$. When the $\mathrm{Fe}^{2+}$ concentration increased, the catalytic effect increased accordingly. However, for $\mathrm{Fe}^{2+}$ doses higher than $5.0 \mathrm{mM}$, the COD per cent removal decreased slightly. This decrease was essentially due to competitive consumption of $\mathrm{OH}^{*}$ radicals (Eq. (4)).

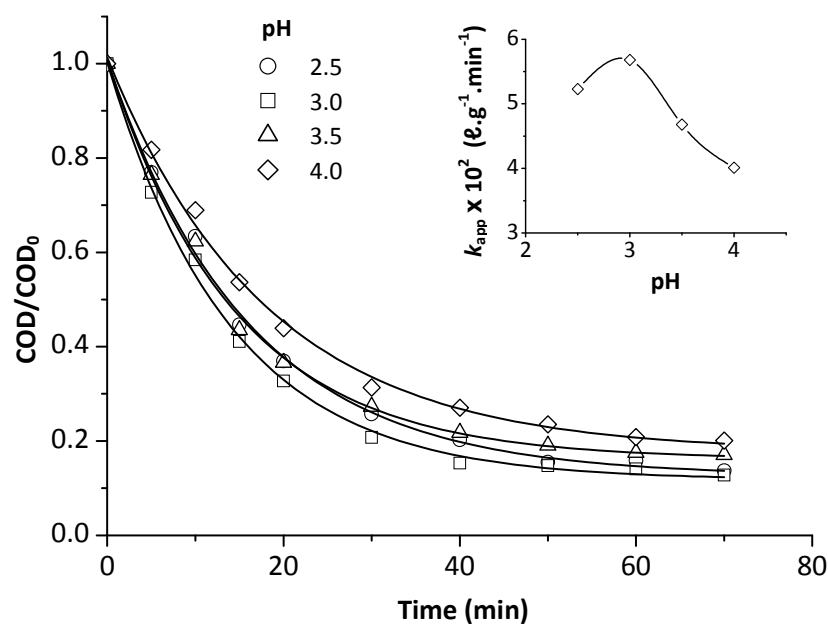

Figure 7

Effect of the initial $\mathrm{pH}$ on the COD removal by the Fenton process. The inset panel shows $k_{\text {ap }}$ evolution at different $\mathrm{pH}$. Dosing rate of $\mathrm{H}_{2} \mathrm{O}_{2} 120 \mathrm{mg} \cdot \mathrm{min}^{-1} ;\left[\mathrm{Fe}^{2+}\right]_{0}=5.0 \mathrm{mM} ; \mathrm{COD}_{0}$ $=1330 \mathrm{mg} \cdot \ell^{-1}$ and $T=25^{\circ} \mathrm{C}$.

It is worth noting that, in the Fenton process, the amounts of $\mathrm{Fe}^{2+}$ ions should be as low as possible for economic and environmental reasons; high amounts of $\mathrm{Fe}^{2+}$ ions might produce a larger quantity of $\mathrm{Fe}^{3+}$ sludge. The removal/treatment of the sludge containing $\mathrm{Fe}^{3+}$ at the end of the wastewater treatment is expensive and requires a large amount of chemicals and manpower (Ramirez et al., 2007). As shown in the inset of Fig. 6, $5.0 \mathrm{mM} \mathrm{Fe}^{2+}$ can be used as an optimum dosage in this work.

\section{Effect of initial $\mathrm{pH}$}

The $\mathrm{pH}$ affects the oxidation of organic substances both directly and indirectly. The Fenton and photo-Fenton reactions are strongly $\mathrm{pH}$-dependent. The $\mathrm{pH}$ value influences the generation of hydroxyl radicals and thus the oxidation efficiency. The effect of $\mathrm{pH}$ on the degradation of chlorpyrifos by the Fenton process is shown in Fig. 7. The experiments were carried out at a $\mathrm{pH}$ within the range of 2.5-4.0. The optimum $\mathrm{pH}$ was found to be about 3, as elucidated by $k_{\text {app }}$ values. The degradation decreased at $\mathrm{pH}$ values higher than 3.5, because iron precipitated as hydroxide.

Additionally, the oxidation potential of the hydroxyl radical was known to decrease with increasing $\mathrm{pH}$ (Lucas and Peres, 2006). Another reason for the inefficient degradation at $\mathrm{pH}>$ 3 is the dissociation and auto-decomposition of $\mathrm{H}_{2} \mathrm{O}_{2}$ (Badawy et al., 2006). For $\mathrm{pH}$ values below 2.5 , the reaction of hydrogen peroxide with $\mathrm{Fe}^{2+}$ is seriously affected causing reduction in hydroxyl radical production, due to hydroxyl-radical scavenging by $\mathrm{H}^{+}$ions (Lucas and Peres, 2006).

\section{Effect of temperature}

The effect of temperature on the kinetic rate constants, $k_{\text {app }}$, for chlorpyrifos degradation was studied at temperatures of 20, 25, $30,35,40$ and $45^{\circ} \mathrm{C}$, with other test conditions of $\mathrm{COD}_{0}=1330$ $\mathrm{mg} \cdot \ell^{-1}, \mathrm{H}_{2} \mathrm{O}_{2}$ dosing rate $=120 \mathrm{mg} \cdot \mathrm{min}^{-1},\left[\mathrm{Fe}^{2+}\right]_{0}=5.0 \mathrm{mM}$ and $\mathrm{pH}=3$. The results obtained are shown in Fig. 8, and clearly indicate that $k_{\text {app }}$ is significantly affected by reaction temperature, increasing with increasing temperature until an optimal value of $35^{\circ} \mathrm{C}$. The decrease of $k_{\text {app }}$ at temperatures higher than $40^{\circ} \mathrm{C}$ is due to the accelerated decomposition of $\mathrm{H}_{2} \mathrm{O}_{2}$ into oxygen and water. Similar results were reported by Wang (2008). 


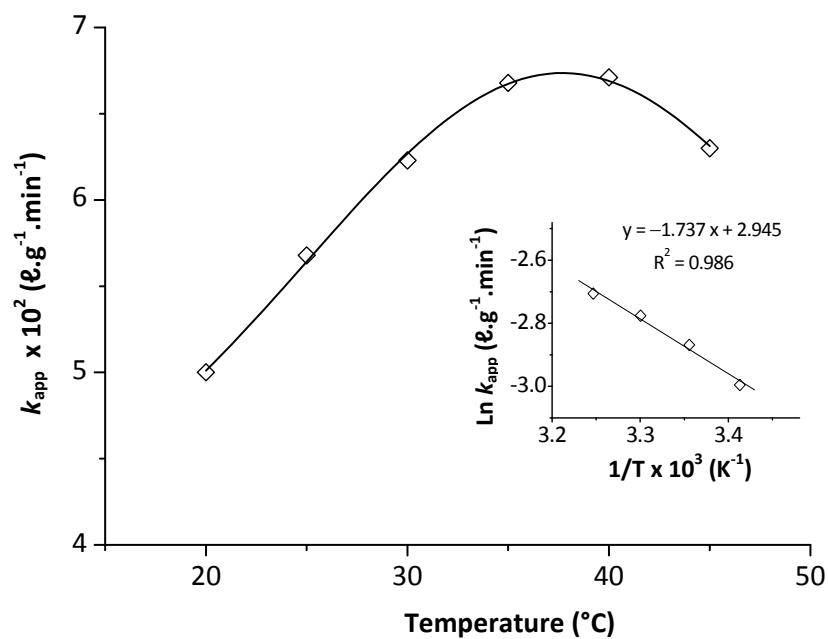

Figure 8

Evolution of $k_{\text {apo }}$ at different temperatures. The inset shows the plot of $\mathrm{Ln} k_{\text {app }}-(1 / \mathrm{T}) . C O D_{0}=1330 \mathrm{mg} \cdot \ell^{-1}$; Dosing rate of $\mathrm{H}_{2} \mathrm{O}_{2}$ $120 \mathrm{mg} \cdot \mathrm{min}^{-1} ;\left[\mathrm{Fe}^{2+}\right]_{0}=5.0 \mathrm{mM}$ and $\mathrm{pH}=3$.

The Arrhenius expression, showing the relationship between the reaction temperature and $k_{\text {app }}$ is expressed as follows:

$$
\mathrm{k}_{\mathrm{app}}=A \exp \left(-\frac{\mathrm{E}_{\mathrm{app}}}{\mathrm{RT}}\right)
$$

where:

$A$ is the pre-exponential (or frequency) factor

$E_{\text {app }}$ is the apparent global activation energy $\left(\mathrm{J} \cdot \mathrm{mol}^{-1}\right)$

$R$ is the ideal gas constant $\left(8.314 \mathrm{~J} \cdot \mathrm{mol}^{-1} \cdot \mathrm{K}^{-1}\right)$

$T$ is the reaction absolute temperature $(\mathrm{K})$.

Due to the narrow temperature range employed in this study (i.e., $20-35^{\circ} \mathrm{C}$ ), variations of the pre-exponential factors and the apparent activation energies of the empirical Arrhenius expressions of the COD removal may be neglected. The variation of Ln $k_{\text {app }}$ versus $1 / T$ is plotted in the inset of Fig. 8. Good linear relationships exist between the plot of $\operatorname{Ln} k_{\text {app }}$ and 1/T because the regression coefficient was higher than 0.98 . Based on the slope $\left(-E_{\text {app }} / R\right)$ and intercepts $(\operatorname{Ln} A)$ of the plot in Fig. 8, $E_{\text {app }}$ and $A$ in Arrhenius form (Eq. (8)) are determined, i.e., $E_{\text {app }} \stackrel{\text { app }}{=}$ $14.44 \mathrm{~kJ} \cdot \mathrm{mol}^{-1}$ and $A=19.01 \ell \cdot \mathrm{g}^{-1} \cdot \mathrm{min}^{-1}$.

\section{Oxidation of chlorpyrifos by the solar photo- Fenton process}

In order to improve the reaction rate and COD abatement efficiency, solutions were subjected to solar radiation using a laboratory-scale reactor (Fig. 2). Fig. 9 shows the trend of the $\mathrm{COD} / \mathrm{COD}_{0}$ ratio during the treatment of chlorpyrifos solution by the 2 processes under the optimum experimental conditions found when using the Fenton process $\left(\mathrm{H}_{2} \mathrm{O}_{2}=120\right.$ $\mathrm{mg} \cdot \mathrm{min}^{-1},\left[\mathrm{Fe}^{2+}\right]_{0}=5.0 \mathrm{mM}, \mathrm{pH}=3$ and $T=35^{\circ} \mathrm{C}$ ). It can be seen that the solar photo-Fenton system needed less time and consequently less $\mathrm{H}_{2} \mathrm{O}_{2}$ to reach the same COD per cent removal. In fact, under the optimum experimental conditions, the solar photo-Fenton process needed a dose of $\mathrm{H}_{2} \mathrm{O}_{2} 50 \%$ lower than that used in the Fenton process to remove $90 \%$ of COD. The COD removal rate is higher with the solar photoFenton process as shown by the $k_{\text {app }}$ values in the inset of Fig. 9.

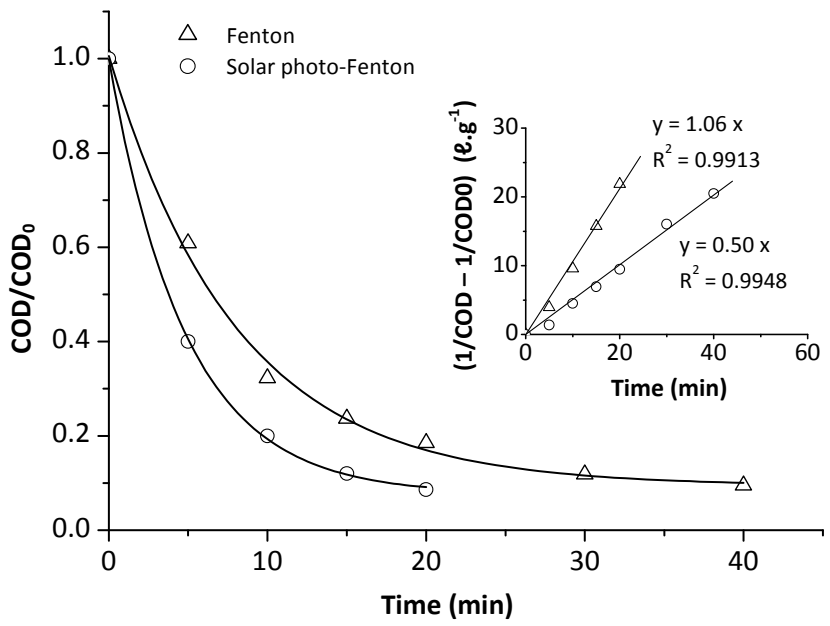

Figure 9

Trend of $C O D / C O D_{0}$ ratio during the oxidation of chlorpyrifos solution by Fenton and solar phto-Fenton reactions. The inset panel shows the fitting of the experimental data to a secondorder reaction kinetic model for the 2 processes. Dosing rate of $\mathrm{H}_{2} \mathrm{O}_{2} 120 \mathrm{mg} \cdot \mathrm{min}^{-1} ;\left[\mathrm{Fe}^{2+}\right]_{0}=5.0 \mathrm{mM} ; \mathrm{COD}_{0}=1330 \mathrm{mg} \cdot \ell^{-1}$; $p H=3$ and $T=35^{\circ} \mathrm{C}$.

\section{Conclusions}

The results of this study indicate that dark Fenton and solar photo-Fenton processes are powerful methods for the degradation of the insecticide chlorpyrifos, but the solar-photoFenton process is $50 \%$ more efficient than the Fenton process. The degradation rate by the 2 processes can be expressed as a pseudo-second-order reaction with respect to COD. COD removal was influenced by the dosing rate of the hydrogen peroxide $\left(\mathrm{H}_{2} \mathrm{O}_{2}\right.$ continuously introduced in the solution), the initial concentration of chlorpyrifos, the amount of iron salt, the $\mathrm{pH}$ of solution and the temperature. The optimum conditions were observed at $\mathrm{pH} 3$, with an initial $\mathrm{Fe}^{2+}$ concentration of $5.0 \mathrm{mM}$ and $\mathrm{H}_{2} \mathrm{O}_{2}$ dosing rate of $120 \mathrm{mg} \cdot \mathrm{min}^{-1}$. The experiments carried out within the temperature range $20-45^{\circ} \mathrm{C}$ showed an optimum COD removal at $35^{\circ} \mathrm{C}$, which allowed for computation of the apparent global activation energy $\left(14.44 \mathrm{~kJ} \cdot \mathrm{mol}^{-1}\right)$.

The results obtained with this preliminary study suggest that solar photo-Fenton is a promising pre-treatment process for pesticide-containing wastewater.

\section{Acknowledgments}

This research was funded by the Tunisian Higher Education and Scientific Research Ministry.

\section{References}

ACERO JL, BENITEZ FJ, GONZALEZ M and BENITEZ R (2002) Kinetics of fenuron decomposition by single-chemical oxidants and combined systems. Ind. Eng. Chem. Res. 41 (17) 4225-4232.

ARGUN ME and KARATAS M (2011) Application of Fenton process for decolorization of reactive black 5 from synthetic wastewater: Kinetics and thermodynamics. Environ. Prog. Sust. Energ. 30 (4) 540-548.

BADAWY MI, GHALY MY and GAD-ALLAH TA (2006) Advanced oxidation processes for the removal of organophosphorus pesticides from wastewater. Desalination 194 (1-3) 166-175. 
BOSSMANN SH, OLIVEROS E, GÖB S, SIEGWART S, DAHLEN EP, PAYAWAN L, STRAUB M, WÖRNER M and BRAUN AM (1998) New evidence against hydroxyl radicals as reactive intermediates in the thermal and photochemically enhanced Fenton reactions. J. Phys. Chem. A 102 (28) 5542-5550.

BURROWS HD, CANLE LM, SANTABALLA JA and STEENKEN S (2002) Reaction pathways and mechanisms of photodegradation of pesticides. J. Photochem. Photobiol. B: Biol. 67 (2) 71-108.

CHIRON S, FERNANDEZ-ALBA A, RODRIGUEZ A and GARCIACALVO E (1999) Pesticide chemical oxidation: state-of-the-art. Water Res. 34 (2) 366-377.

CUNNIF P (1995) Official Methods of Analysis of AOAC International (16 ${ }^{\text {th }}$ edn.). AOAC international, Arlington. ISBN/ISSN 0935584544.

DERCO J, GOTVAJN AZ, ZAGORC-KONCAN J, ALMASIOVA B and KASSAI A (2010) Pretreatment of landfill leachate by chemical oxidation processes. Chem. Pap. 64 (2) 237-245.

DI CORCIA A and MARCHETTI M (1992) Method development for monitoring pesticides in environmental waters: Liquid-solid extraction followed by liquid chromatography. Environ. Sci. Technol. 26 (1) 66-74.

ESPLUGAS S, GIMÉNEZ J, CONTRERAS S, PASCUAL E and RODRIGUEZ M (2002) Comparison of different advanced oxidation processes for phenol degradation. Water Res. 36 (4) 1034-1042.

GUEDES AMFM, MADEIRA LMP, BOAVENTURA RAR and COSTA CAV (2003) Fenton oxidation of cork cooking wastewater - overall kinetic analysis. Water Res. 37 (13) 3061-3069.

HABER F and WEISS J (1934) The catalytic decomposition of hydrogen peroxide by iron salts. Proc. R. Soc. A 147 (861) 332-351.

KANG N, LEE DS and YOON J (2002) Kinetic modeling of fenton oxidation of phenol and monochlorophenols. Chemosphere 47 (9) 915-924.

KANG YW and HWANG KY (2000) Effects of reaction conditions on the oxidation efficiency in the Fenton process. Water Res. 34 (10) 2786-2790.

KOLTHOF IM, SANDELL EB, MEEEHAN EJ and BUCKSTEIN S (1969) Quantitative Chemical Analysis (4 ${ }^{\text {th }}$ edn.). Macmillan, New York.

LIN SH and LO CC (1997) Fenton process for treatment desizing wastewater. Water Res. 31 (8) 2050-2056.

LUCAS MS and PERES JA (2006) Decolorization of the azo dye reactive black 5 by Fenton and photo-Fenton oxidation. Dyes Pigm. 71 (3) 236-244.

MENG JW, YANG B, ZHANG Y, DONG X and SHU J (2010) Heterogeneous ozonation of suspended malathion and chlorpyrifos particles. Chemosphere 79 394-400.

MODIRSHAHLA N, BEHNAJADY MA and GHANBARY F (2007) Decolorization and mineralization of C.I. acid yellow 23 by Fenton and photo-Fenton processes. Dyes Pigm. 73 (3) 305-310.

MURILLO R, SARASA J, LANAO M and OVELLEIRO JL (2010) Degradation of chlorpyrifos in water by advanced oxidation processes. Water Sci. Technol. 10 (1) 1-6.

PIGNATELLO JJ (1992) Dark and photoassisted iron(3+)-catalyzed degradation of chlorophenoxy herbicides by hydrogen peroxide. Environ. Sci. Technol. 26 (5) 944-951.

RAMIREZ JH, COSTA CA, MADEIRA LM, MATA G, VICENTE MA, ROJAS-CERVANTES ML, LOPEZ-PEINADO AJ and MARTIN-ARANDA RM (2007) Fenton-like oxidation of Orange II solutions using heterogeneous catalysts based on saponite clay. Appl. Catal. B: Environ. 71 (1-2) 44-56.

RATANATAMSKUL C and AUESUNTRACHUN P (2009) Removal of COD and colour from old-landfill leachate by Advanced Oxidation Processes. Int. J. Environ. Waste Manage. 4 (3-4) 470-480.

SAMET Y, AGENGUI L and ABDELHEDI R (2010) Anodic oxidation of chlorpyrifos in aqueous solution at lead dioxide electrodes. $J$. Electroanal. Chem. 650 152-158.

TAMIMI M, QOURZAL S, BARKA N, ASSABBANE A and AITICHOU Y (2008) Methomyl degradation in aqueous solutions by Fenton's reagent and the photo-Fenton system. Sep. Purif. Technol. 61 (1) 103-108.

WALLING C (1975) Fenton's reagent revisited. Acc. Chem. Res. 8 (4) $125-131$.

WANG S (2008) A comparative study of fenton and fenton-like reaction kinetics in decolorisation of wastewater. Dyes Pigm. 76 714-720.

XU M, WANG Q and HAO Y (2007) Removal of organic carbon from wastepaper pulp effluent by lab-scale solar photo-Fenton process. J. Hazard. Mater. 148 103-109. 